\title{
Small Hydropower Plants in Generation in the Rural Area of the West and Southwest of Paraná State-Brazil
}

\author{
Fabrício Ströher da Silva ${ }^{1}$, Jair Antonio Cruz Siqueira ${ }^{1}$, Carlos Eduardo Camargo Nogueira ${ }^{1}$, \\ Maritante Prior $^{1} \&$ Luciene Kazue Tokura ${ }^{1}$ \\ ${ }^{1}$ Post-Graduation Program in Engineering of Energy in Agriculture, State University of West Paraná, Cascavel, \\ Paraná, Brazil \\ Correspondence: Luciene Kazue Tokura, Post-Graduation Program in Engineering of Energy in Agriculture, \\ State University of West Paraná, Rua Universitária, 2069-Jardim Universitário, CEP: 85819-110, Cascavel, \\ Paraná, Brazil. Tel: 55-453-220-3151. E-mail: lucienetokura@gmail.com
}

$\begin{array}{lc}\text { Received: May 11, } 2019 & \text { Accepted: June 28, } 2019 \quad \text { Online Published: August 15, } 2019 \\ \text { doi:10.5539/jas.v11n13p213 } & \text { URL: https://doi.org/10.5539/jas.v11n13p213 }\end{array}$

\begin{abstract}
Hydropower generation is the main source of electric energy in Brazil and the West and Southwest of Paraná. Year after year the energy matrix has been diversifying, including new sources, such as wind power. However, due to the power accumulation characteristic of hydropower, this type of source is important for the stability of the electric system. Currently, hydropower corresponds to just over $60 \%$ of all power installed in Brazil. Particularly in the West and Southwest region of Paraná, this number increases, and Paranás share in the Brazilian matrix is approximately $16 \%$ of the installed potential. This compromises the productive areas of these regions by the flood generated by the plants. In order to verify the participation of these regions in the hydropower matrix and its production, a survey was made of the installed potential and the constructive profile of the hydroenergy projects. In addition, the flow and production trend of the Salto Santiago hydropower in the Iguaçu River watershed and the Melissa hydropower in the Piquiri River watershed were verified during the period from 2003 to 2017. Finally, a conceptual map of the western and southwestern regions of Paraná was elaborated with the hydropower generation profile. It was concluded by the survey that the regions of the study have great participation in the hydropower matrix of Brazil and that its production and the flow of the rivers in the entrance of these remains practically unchanged in the studied period.
\end{abstract}

Keywords: power, small hydropower, hydroelectric energy

\section{Introduction}

The main source of electrical energy generation in Brazil and Paraná is the hydropower. Other sources of centralized power generation are used only when hydraulics cannot meet this demand (Filho, 2013). The state of Paraná represents $16 \%$ of the total number of enterprises installed in Brazil (ANEEL, 2017).

Among the watershed in the state of Paraná, the most important are the Iguaçu River watershed, with the largest number of small hydropower (SHP) (Kliemann \& Delariva, 2015). In addition, along with the Iguaçu River watershed, the Piquiri River watershed has a potential of 809 MW hydropower (HP), as well as SHP's (EPE, 2015).

More rapidly, demand for electricity has been rising in recent years and there is a projection by the EPE (2016) of a $33 \%$ increase in demand for electricity compared to 2015 . This is mainly due to new technologies and easier access to electrical equipment such as electronics and appliances.

This increase in consumption is evident in the last three decades, where the annual increase in consumption averaged $7.8 \%$ higher. This increase is due to the increase in consumer units and also to the average consumption per consumer (Oliveira \& Moura, 2015).

Although there is a considerable increase in the self-generation of electrical energy through distributed generation (ANEEL, 2015). This generation, according to estimates from EPE (2016), will correspond to only $10 \%$ of the electrical energy demand, which represents a high dependence on the larger plants. 
As previously mentioned, Brazil has its electric potential, mainly due to hydropower, a fact that few countries have this privilege, since geographic conditions, availability and territorial extension are primordial factors (Neto \& Carvalho, 2013).

In addition to internally having its potential mainly supplied by hydropower, Brazilian production is also the highlight in the world, where in 2010 it was the 2nd largest producer of electric energy from hydropower with $403 \mathrm{TWh}$ (IIEA, 2012). According to the same document, the estimate was that the hydroelectric production presented little increase in production. However, it maintained its prominence in world production.

The state of Paraná has the highest electricity production from hydropower, in which $90 \%$ of the energy generated in the state was provided by hydropower. The rest of the installed power was divided between thermoelectrical and wind energy (ANEEL, 2017).

According to data from ANEEL (2017), the state of Paraná will double the number of SHP-type enterprises and the representation of its production in the state will increase from $0.17 \%$ to $0.32 \%$. This small percentage that represents the SHP's is low because the largest plant in Latin America, the Itaipú plant is located in the state of Paraná.

Thus, studies are needed to evaluate the use of water resources, in order to meet the demand that, according to Blois et al. (2017), tends to increase along with national economic growth.

In view of the above, this work had as objective to determine the profile of the hydropower generation in the West and Southwest of Paraná in Brazil.

\section{Material and Methods}

\subsection{Characterization of the Regions Under Study}

This work has as scope the western and southwestern regions of the state of Paraná. Figure 1 shows the state of Paraná with its divisions in its mesoregions, highlighting the study regions of this work, which are the West and Southwest regions of the state of Paraná.

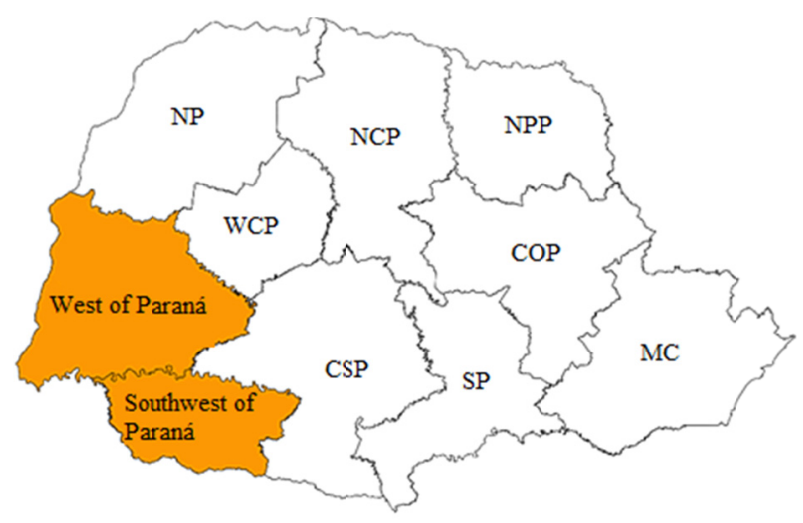

Figure 1. State of Paraná subdivided into mesoregions with emphasis on the West and Southwest regions

Note. NP: Northwest of Paraná; WCP: Western Center of Paraná; CSP: South Central of Paraná; NCP: North Central Paraná; SP: Southeast of Paraná; NPP: Northern Pioneer of Paraná; COP: Eastern Center of Paraná; MC: Metropolitan of Curitiba.

These regions are located in three distinct watersheds, the Piquiri River watershed, the Iguaçu River watershed and the Paraná River watershed.

The flooding of areas for the production of electric energy was quite expressive. Considering only the Itaipu plant, it flooded $4 \%$ of the western region of Paraná as described by Casagrande and Souza (2013). The reduction of the economic impact of these floods was reduced by the payment of royalties that aid in the development of cities that had its area compromised by the flood generated by the plants.

The western region of Paraná was the last region of the state to be colonized, and this process began in the mid-1940s (Magalhães, 1998). 
The colonization of the southwestern region, although populated by Indians and native peoples, began in 1943 with the creation of the ACGO (Agricultural Colony General Ozório), whose purpose was to install families of farmers in the region, who came mainly from the states of Rio Grande do Sul and Santa Catarina (Zatta, 2016).

The watershed of the Iguaçu River (Note 1) is the one that most concentrates hydroelectric ventures of the SHP's type along with the Ivaí River watershed, but the first one, although with a number of projects equal to that of the other watershed, has a greater installed potential, according to Kliemann and Delariva (2015).

Figure 2 shows the watershed of the Iguaçu River that starts in the metropolitan region of Paraná to the city of Foz do Iguaçu, where the Paraná River watershed joins. Figure 2 also highlighted the part of the watershed that belongs to the West and Southwest region of Paraná.

The Piquiri River watershed has a drainage area of 24,156 $\mathrm{km}^{2}$ according to SEMA (2008) and it is presented in Figure 3 .

In the region of the study, the Piquiri River watershed has only two hydropower projects, although it is possible to build new ventures in this watershed according to EPE (2015).

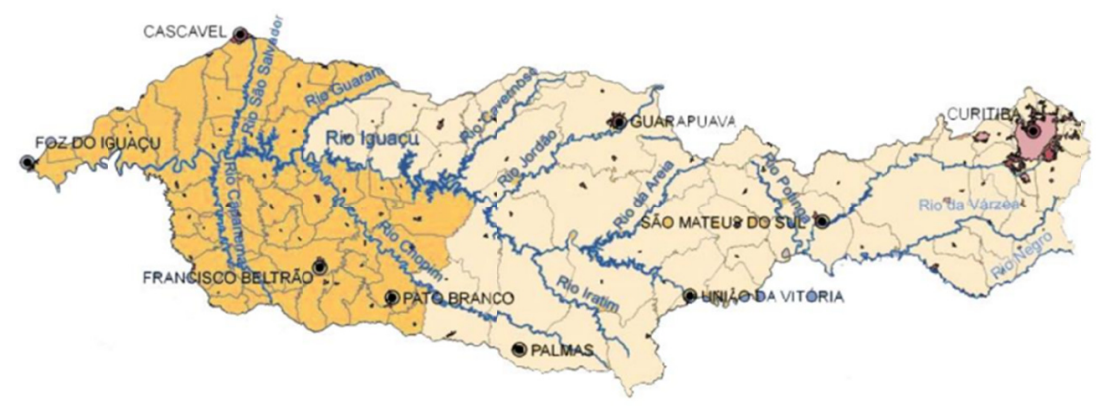

Figure 2. Watershed of the Iguaçu river, highlighting the area inserted in the West and Southwest regions of the Paraná. Adapted from Secretary of Environment and Hydric Resources (SEMA) (2008)

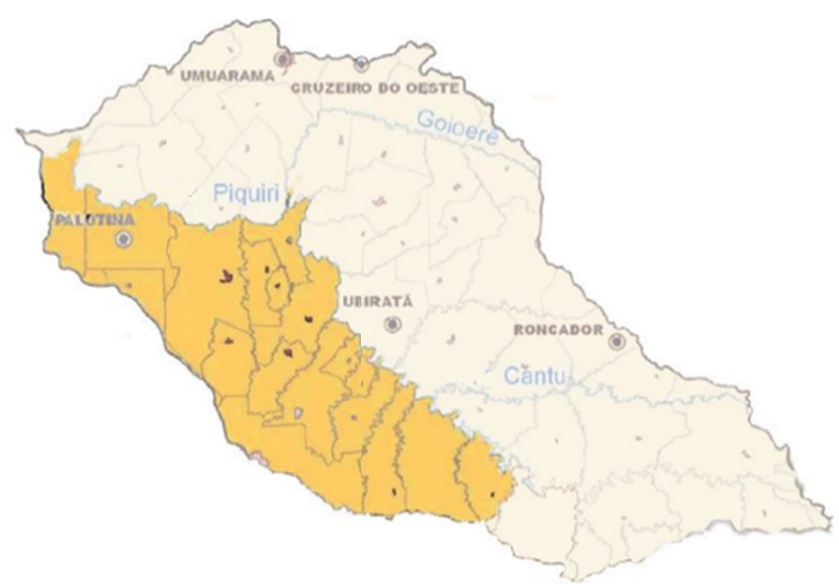

Figure 3. Piquiri River watershed, highlighting the western and southwestern region of Paraná. Adapted from SEMA (2008)

The watershed of the Paraná River 3 is completely inserted in the western region of Paraná and its main hydropower project is the Itaipú power plant. This river has a lake all over the watershed and for this reason there is no difference in height between the beginning of the watershed and the dam of Itaipu, a dam that is $120 \mathrm{~m}$ high (DaftLogic, 2018).

Figure 4 shows watershed of the Paraná River 3, with a large area occupied by the Itaipu lake.

Although the Itaipú plant is the largest in the watershed there are other smaller hydropower projects. 
2.2 Hydrological Aspects of the Watersheds and Analysis of Hydroelectric Generation in the West and Southwest Regions of Paraná

The hydrological data of the Piquiri and Iguaçu Rivers were collected through data from the rainfall and fluviometric stations, which are the responsibility of COPEL Generation and Transmission S.A. and ENGIE Brazil Energy, which provided the data of their stations near the study site.

With these data added to the generation data, it was possible to determine a future and life estimate of the projects, using the method of the least squares to determine the tendency of generation of the hydroelectric developments in the analysis sites.

Due to the great dispersion of data due to the seasonal nature of the hydrological variables, a data filter was performed. With this we used only data that are between the second and fourth quartile of the bloxpot graph, since they represent the second dispersion (Neto et al., 2017).

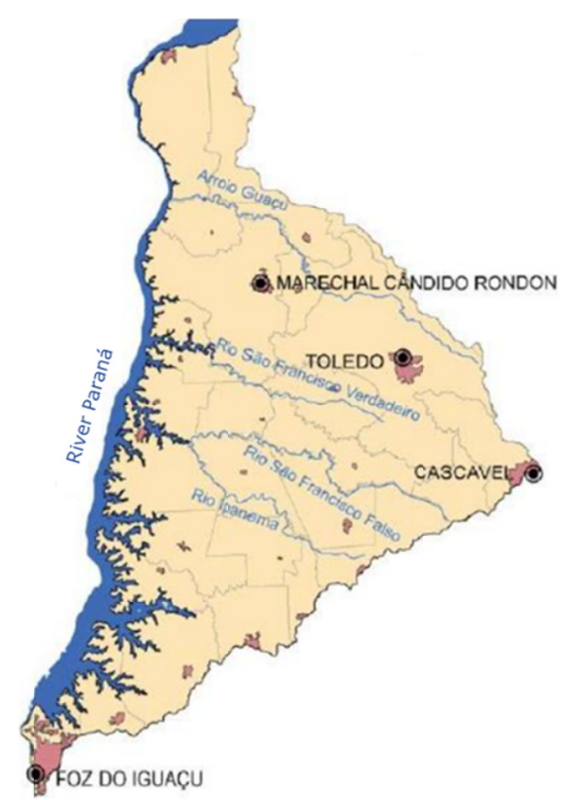

Figure 4. Watershed of the Paraná River 3

These data were collected from the Salto Santiago and Melissa plants in the Iguaçu and Piquiri River watersheds, respectively.

\subsection{Installed Load Data, Characteristics and Number of Hydropower Ventures}

The installed load data were determined through consultation with ANEEL and COPEL.

The characteristic data of the hydroelectric plants refer mainly to the type of turbine used in the construction. These data were obtained by the company Flessak Electro Industrial S.A. through its division of energy generation and also by companies owning the hydroenergy enterprises. However, not all companies provided these data which were left out of the conceptual map of hydroenergy enterprises

\subsection{Map of Distribution of the Hydroenergetic Projects in the West and Southwest of Paraná}

For the elaboration of a distribution map of hydroenergy projects, the QGis software was used, with the help of native tools, to include drainage areas in the conceptual framework.

For the determination of the drainage network, Digital Elevation Models (MDE) of thirty meters of spatial resolution were obtained from the database of the National Institute of Space Research (INPE), through the TOPODATA platform. All data processing was performed in the QGIS 2.14 software. Initially the scenes went through a process of union, to cover the whole area of interest. Afterwards they were converted to a flat projection in order to continue their processing. Subsequently they were submitted to a filtering process, to remove spurious depressions of the MDE, using the process r.fill.dir, of the module GRASS. Then the drainage channels were extracted with the r.watershed process, which were later converted to the vector format (shapefile) 
after proceeding with the mapping, using the print composer, containing the other data presented, such as geographical location of hydroelectric projects.

\section{Results and Discussion}

\subsection{Installed Load Data, Characteristics and Number of Hydroenergetic Enterprises}

From the research of the data provided by ANEEL, it was verified that in operation in the West and Southwest regions of Paraná there are eighteen hydroenergetic projects. Of these, three are of HP (Hydropower) type, four are SHP (Small Hydropower Plants) and eleven are PGH (Power Generation of Hydroelectricity). These values subdivided into percent values are shown in Figure 5.

The installed load in these projects totals 16,722 MW, and in almost all of this amount is installed in HP-type plants.

Figure 6 shows the subdivision of the installed power between HP and SHP, which corresponds to $99.9 \%$ of the installed load, leaving only $0.1 \%$ of the power, which is centralized in power plants of the type PGH, representing the largest number of enterprises.

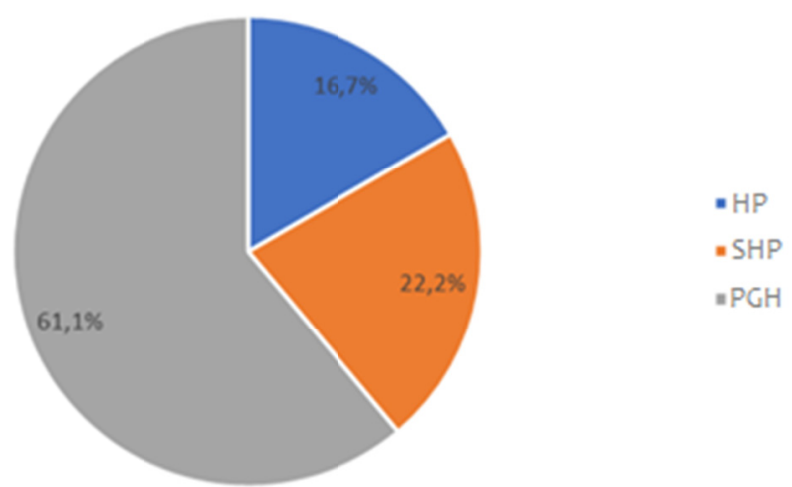

Figure 5. Percentage division of hydroenergy enterprises types in the West and Southwest of Paraná Note. HP: Hydropower; SHP: Small Hydropower Plants; PGH: Power Generation of Hydroelectricity.

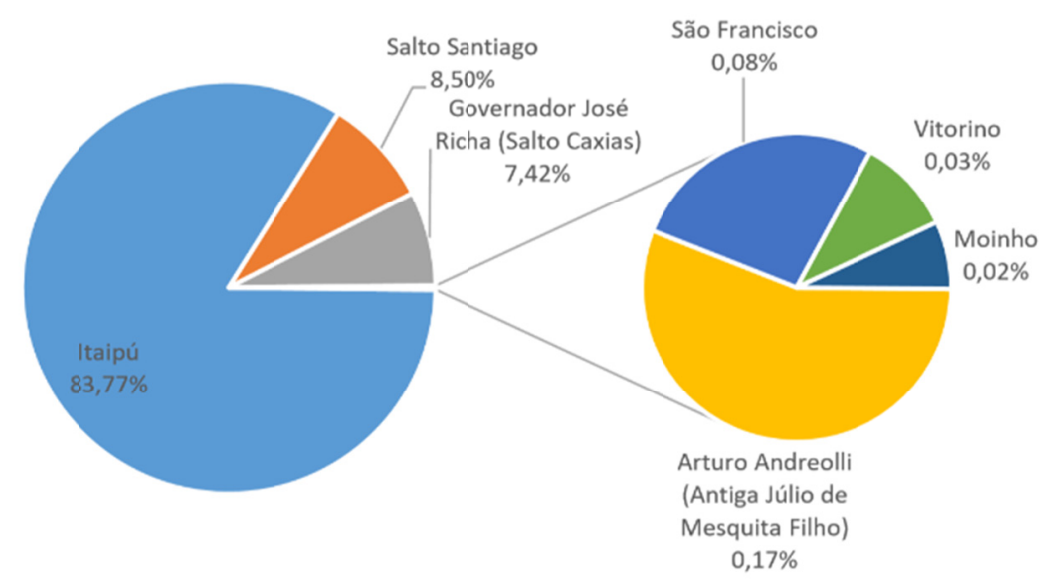

Figure 6. Power distribution in HP and SHP

This installed power corresponds to approximately $17 \%$ of top hydraulic potential installed in Brazil. The subdivision of the potential installed in the West and Southwest regions of Paraná in relation to the Brazilian potential is presented in Figure 7.

It should be noted that the area occupied by the West and Southwest regions of Paraná correspond to only $0.4 \%$ of the national territory. 
Although water use for electric power generation is very significant in the western and southwestern regions of Paraná, there is still no connection made in the format of normative resolution 482 of April 17, 2012 that regulates distributed generation in the country during the period surveyed.

The turbines used predominantly in hydroenergetic ventures in the West and Southwest of Paraná, are of the Francis type. The largest turbines are those installed at the Itaipú Power Plant with a nominal power of each turbine of $700 \mathrm{MW}$ while one of the smaller turbines is installed in Garcia's PGH with individual power of each $500 \mathrm{~kW}$ turbine.

In relation to the Francis type turbines, the same is in the regions in SHP and HP type plants whose waterfalls are higher. Different from what happens in the PGHs, where the predominance is of Kaplan type turbines.

The work was based on hydroenergetic ventures installed in the West and Southwest of Paraná that were in operation at the time of the research work, but on site visits it was verified that ventures were out of operation. An example of this is Garcia's PGH, which does not produce energy for a few years, but which appears as in operation for ANEEL.

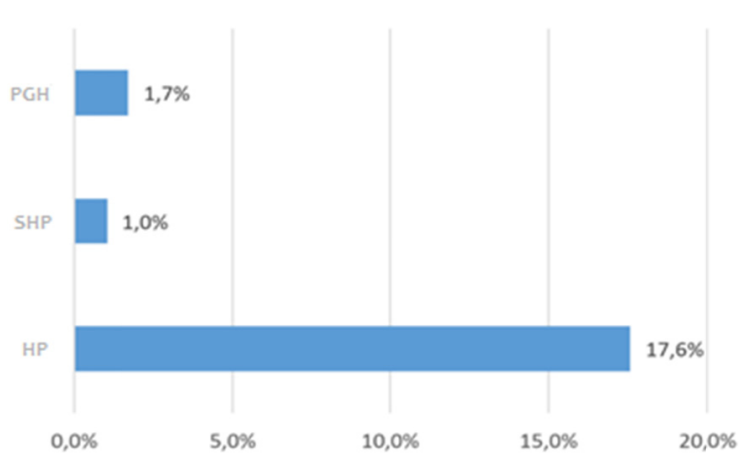

Figure 7. Installed power in ventures in the West and Southwest regions of Paraná in relation to the total installed in Brazil

Note. HP: Hydropower; SHP: Small Hydropower Plants; PGH: Power Generation of Hydroelectricity.

Figure 8 shows an image of Garcia's PGH that appears abandoned and is not in operation for some years according to the information of the people who live in the vicinity of the plant.

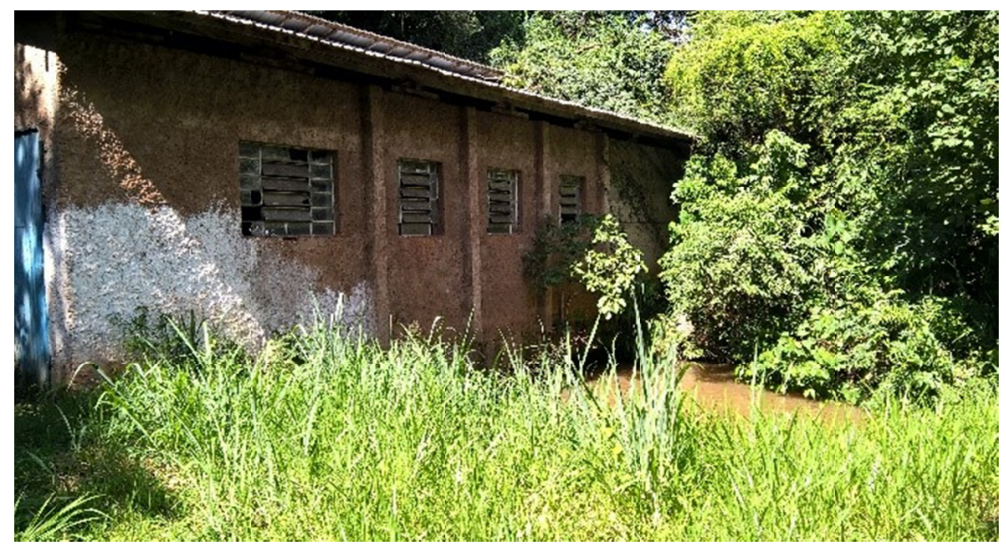

Figure 8. Garcia’s PGH façade

\subsection{Hydrological Aspects of the Watersheds and Analysis of Hydropower Generation in the West and Southwest Regions of Paraná}

In the Iguaçu river watershed, the Salto Santiago plant was evaluated in relation to its electric power production and its hydrological data. 
In Figure 9, it can be seen that in approximately $70 \%$ of the whole period from January 2003 to December 2017 , the affluence of the Iguaçu River maintained values between 600 and $750 \mathrm{~m}^{3} / \mathrm{s}$.

In order to determine a trend of the river flow and consequent the possible future generation of the Salto Santiago plant, the valid historical values of the flows were used and arranged in a graph as a function of time.

To determine the valid flow values a boxplot graph was used and only the values between the first and third quartiles were used. This graph is shown in Figure 10.

It is possible to see in Figure 10 many values outside the maximum limit of the boxplot graph, these values above the upper limit of the graph were possibly generated by the excess of rains in a given period, causing in a flow much higher than normal for that locality. This flow reached a maximum value of $15397,06 \mathrm{~m}^{3} / \mathrm{s}$, which is a flow with double values in relation to the presented in the previous paragraphs.

The valid values or interquartile values used during the graphs are between $1354.06 \mathrm{~m}^{3} / \mathrm{s}$ and $662 \mathrm{~m}^{3} / \mathrm{s}$.

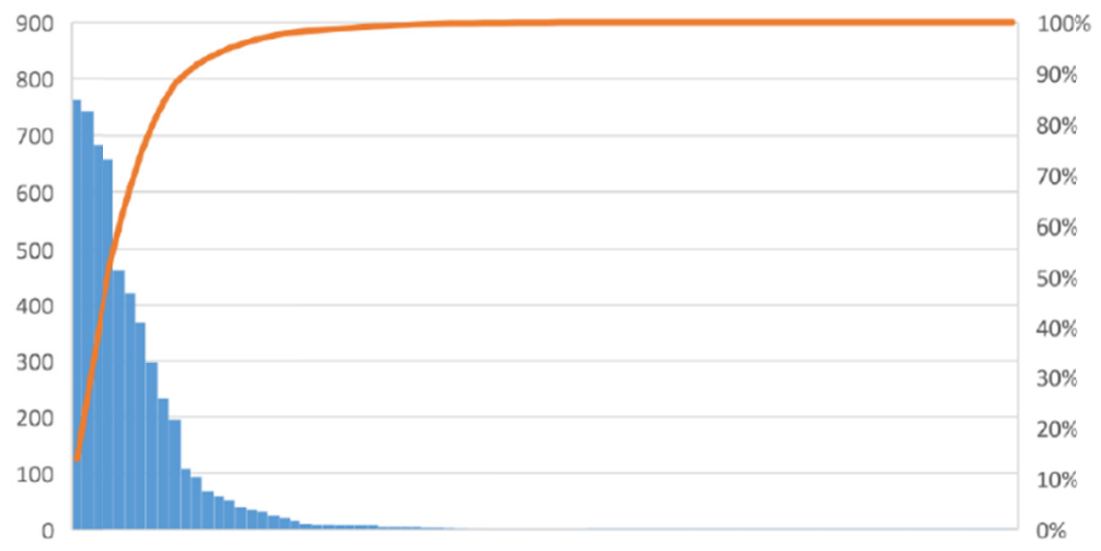

Figure 9. Pareto graphic of the Salto Santiago plant affluence

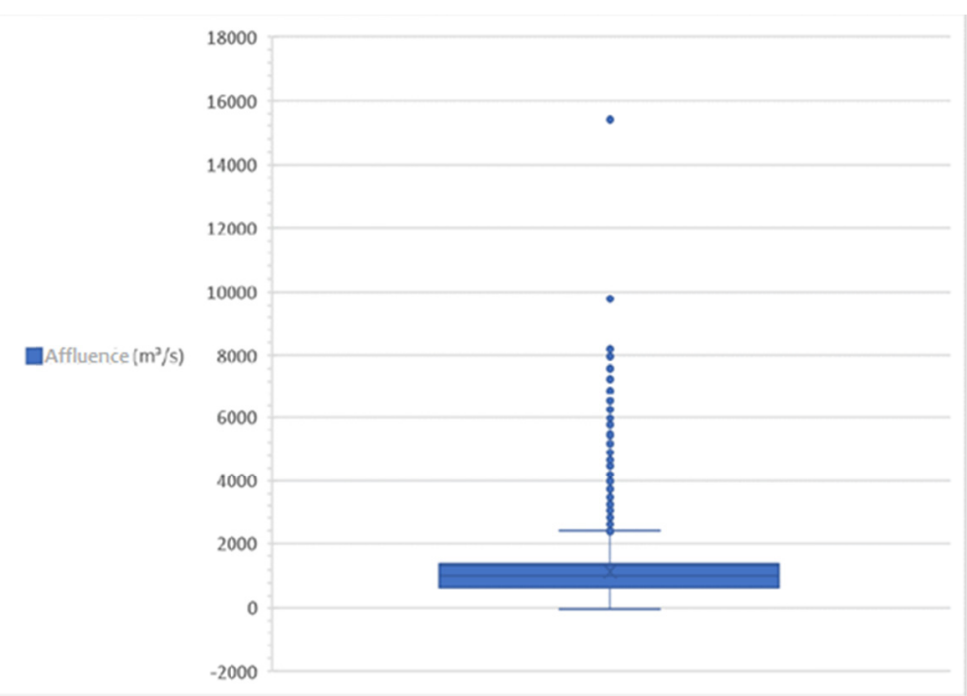

Figure 10. Boxplot of the affluence of the Salto Santiago plant

Figure 11 shows the historical flow of the Salto Santiago plant, in which the line of linear trend that shows a tendency of elevation of the river flow is perceptible. However, $\mathrm{R}^{2}$ (multiplicative factor) information is much less than 1 .

This low value of $\mathrm{R}^{2}$ demonstrates that the trend cannot be considered but gives an idea of historical maintenance of the flow in the power plant. 
Different from what happens with the flow, the electric power production in the Salto Santiago plant has a smaller variation due to the greater control of the use of the river flow.

Even so, the production data was distributed in a boxplot graph for the use of valid values only. This graph is shown in Figure 12.

In the Figures are presented the values to be used which are the productions between 458,781 MWh and 756,796 MWh.

Similar to that shown in Figure 11, Figure 13, which shows the historical production of the Santiago jumping plant, also shows a trend of production growth that has a direct influence on the flow of the river. In the same way as in the flow graph this trend cannot be considered true because $\mathrm{R}^{2}$ is extremely low, far from the ideal value that would be 1 .

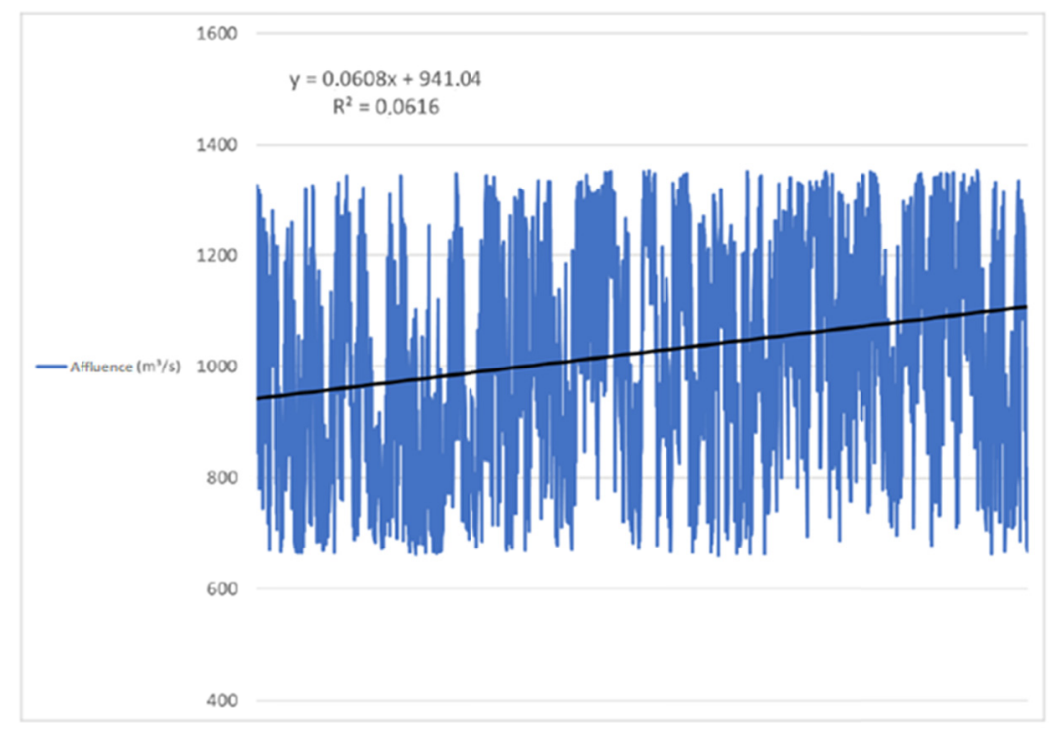

Figure 11. Flow history from 2003 to $2017 \mathrm{in} \mathrm{m}^{3} / \mathrm{s}$

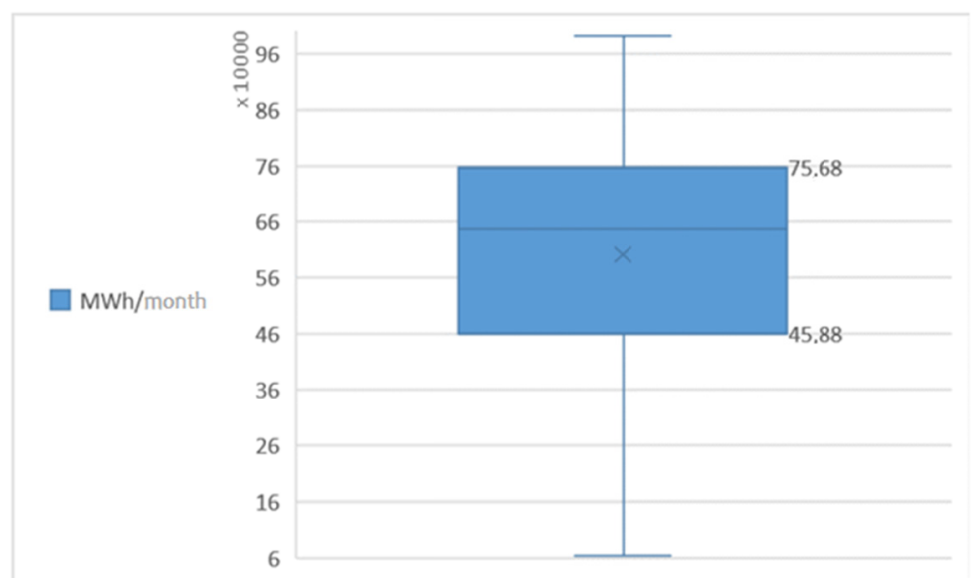

Figure 12. Boxplot of the production in MWh, from the Salto Santiago plant, from 2003 to 2017

The Salto Santiago plant is closer to the mouth of the Iguaçu River than to its source, because of this the influence of rainfall on the flow of the river covers a large area in the watershed.

In the Piquiri River watershed, the same study presented previously was carried out at the Salto Santiago plant. In the Piquiri River watershed, the study was carried out at the Salto Melissa plant located in the municipality of Nova Aurora. 
Because it is a PGH, its production is smaller compared to the Salto Santiago plant, if it also reduces proportionally the river flow. This flow represented in a boxplot distribution is shown in Figure 14.

In this graph also appear values outside the maximum limit of the boxplot chart, also known outliers, that are coming from rains above the average in a short period.

Although shown in Figure 15, the flow tendency in the Melissa river has a negative tendency, it has a very low $\mathrm{R}^{2}$ value, as in the case of the Iguaçu River flow in the Salto Santiago plant. So, it is not possible to say that the flow in the river is actually reducing considering this linear approximation.

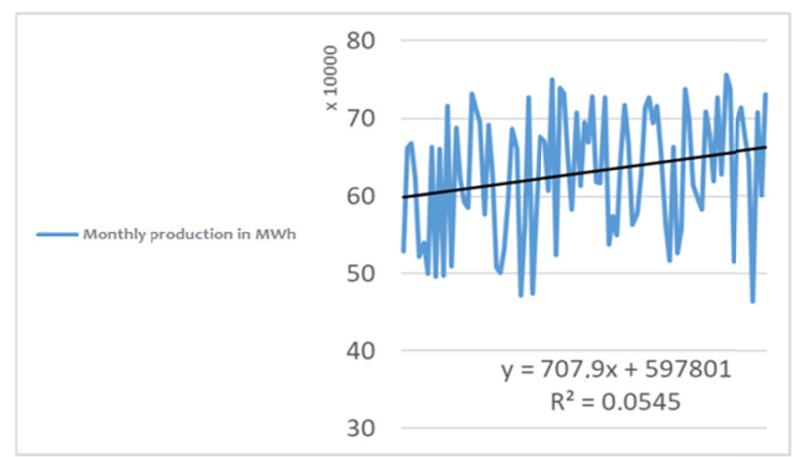

Figure 13. Monthly Production History in MWh of 2003 and 2017 of the Salto Santiago plant

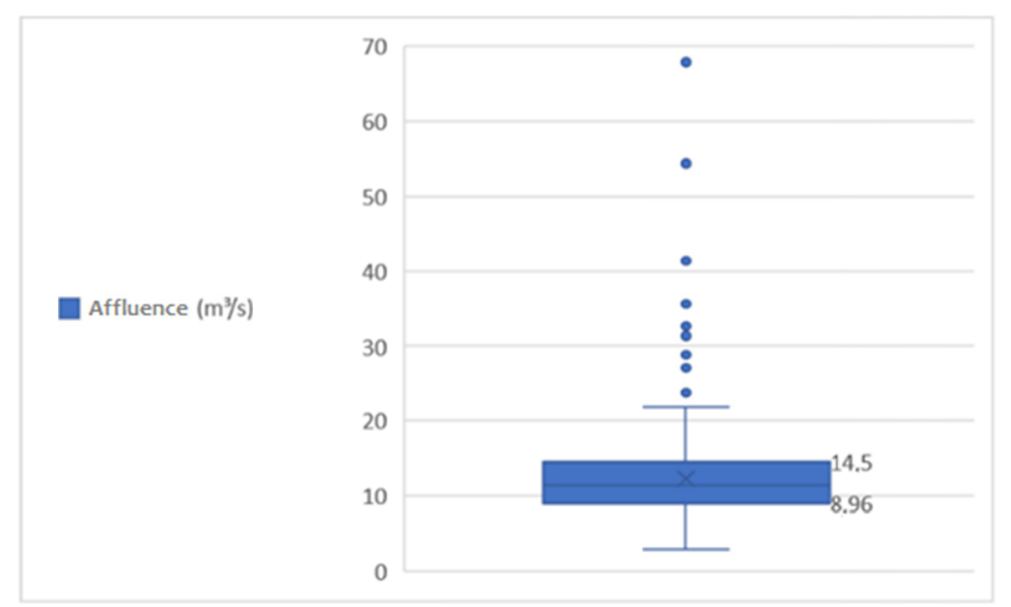

Figure 14. Boxplot of the daily flow of the Melissa plant from 2003 to 2017

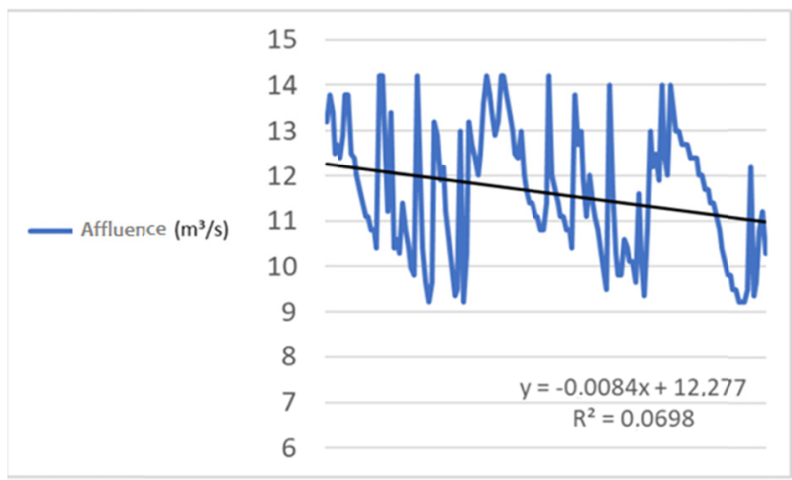

Figure 15. Daily flow history in $\mathrm{m}^{3} / \mathrm{s}$ of the Melissa plant and its linear trend 


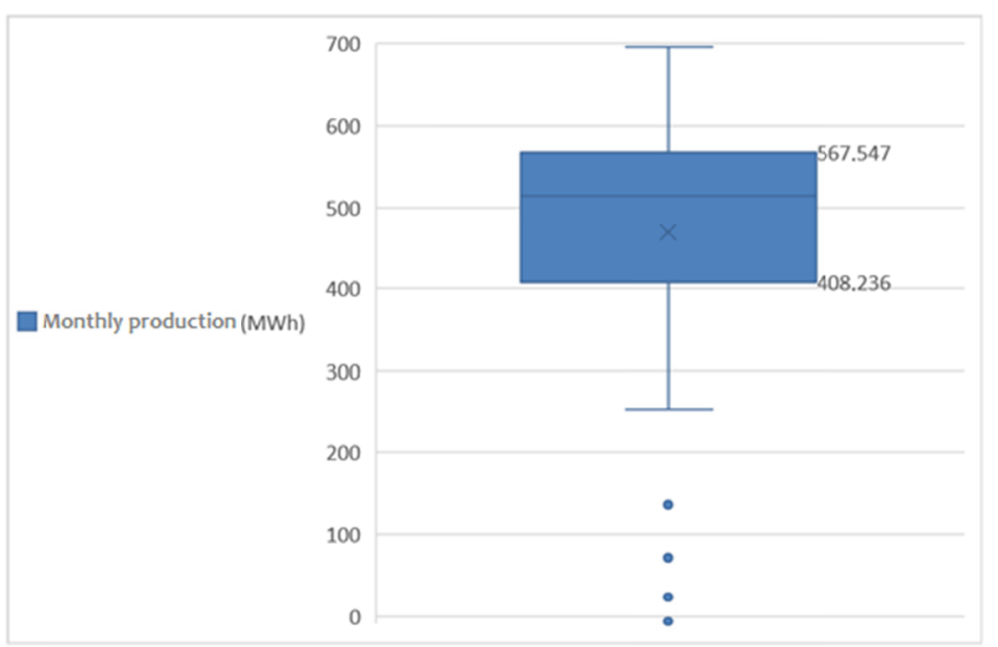

Figure 16. Boxplot of the historical production of the Salto Melissa plant between the years of 2003 and 2017

Figure 16 shows the boxplot of the historical production of the Melissa jump plant; which graph shows some values below the minimum production value. These figures are 4 out of a total of 180 measurements. These outliers, different from those presented in the flow graph, indicate a random error, probably in the measurement of the sensors or their reading.

However, for the valid values considered for determination of historical production, values between 408 and 567 MWh were used, which are the values between the first and fourth quartile of the graph.

With this it was possible to determine the graph of historical production in the time domain, this information is presented graphically in Figure 17.

\subsection{Conceptual Map}

Figure 18 shows the map with the distribution of hydroelectric projects subdivided by their types. Although the drainage area does not necessarily represent the existence of rivers in that area, a small use of the regional potential can be verified.

In the Iguaçu river watershed, this river, which makes the border of the western and southwestern regions of Paraná, is not used for hydroelectric use in the part of the western mesoregion of Paraná, being these areas to be studied for the implementation of hydroelectric projects.

In all the projects in which the type of turbine used was used, it can be observed that in the West and Southwest regions of Paraná, Francis turbines are used for the HP and SHP and the Kaplan Type for projects with smaller waterfalls.

As can be seen from the representation of the drainage area of the West and Southwest regions of Paraná, there is still potential to be explored near the mouth of the Iguaçu River and in the Piquiri River watershed.

Today there is at least the intention to install three HP-type projects in the western region of Paraná, in the Piquiri River watershed (EPE, 2015). New smaller projects are also planned in the affluent rivers. 


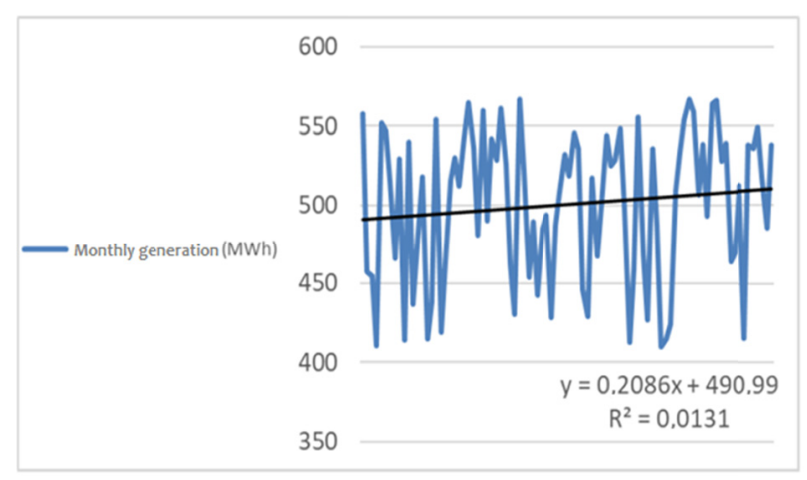

Figure 17. Production of electric power from the Melissa plant between 2003 and 2017

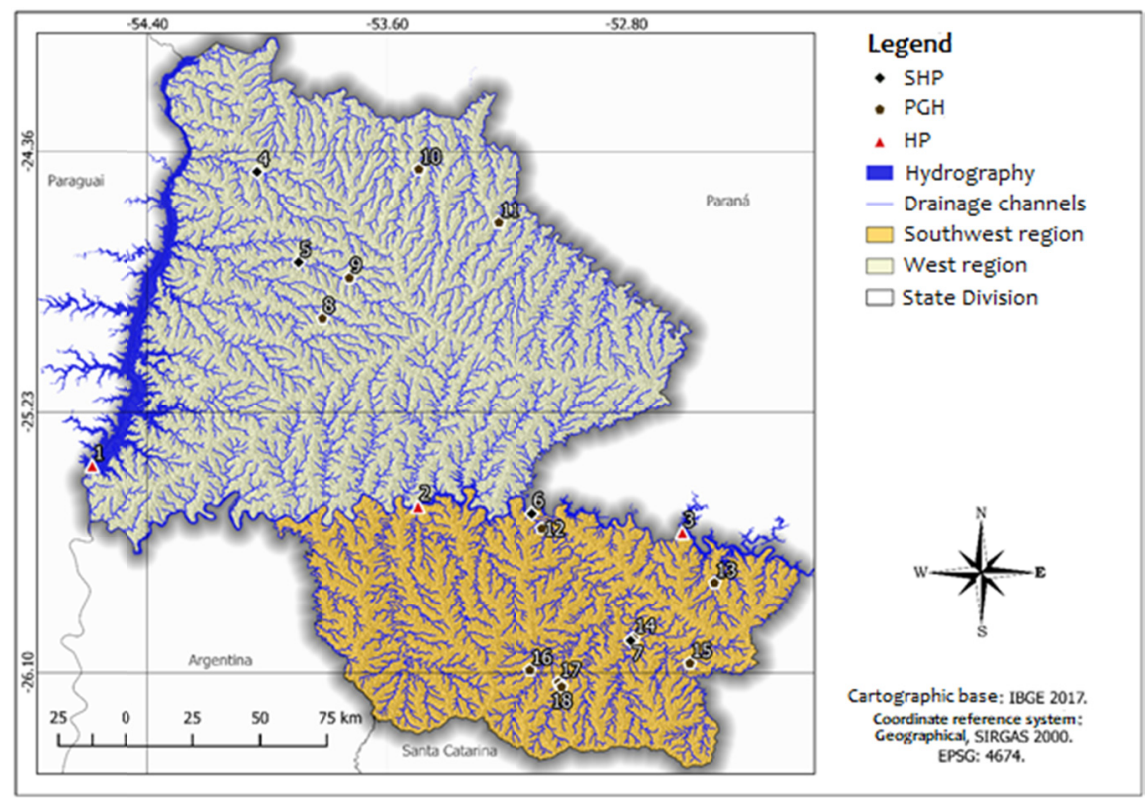

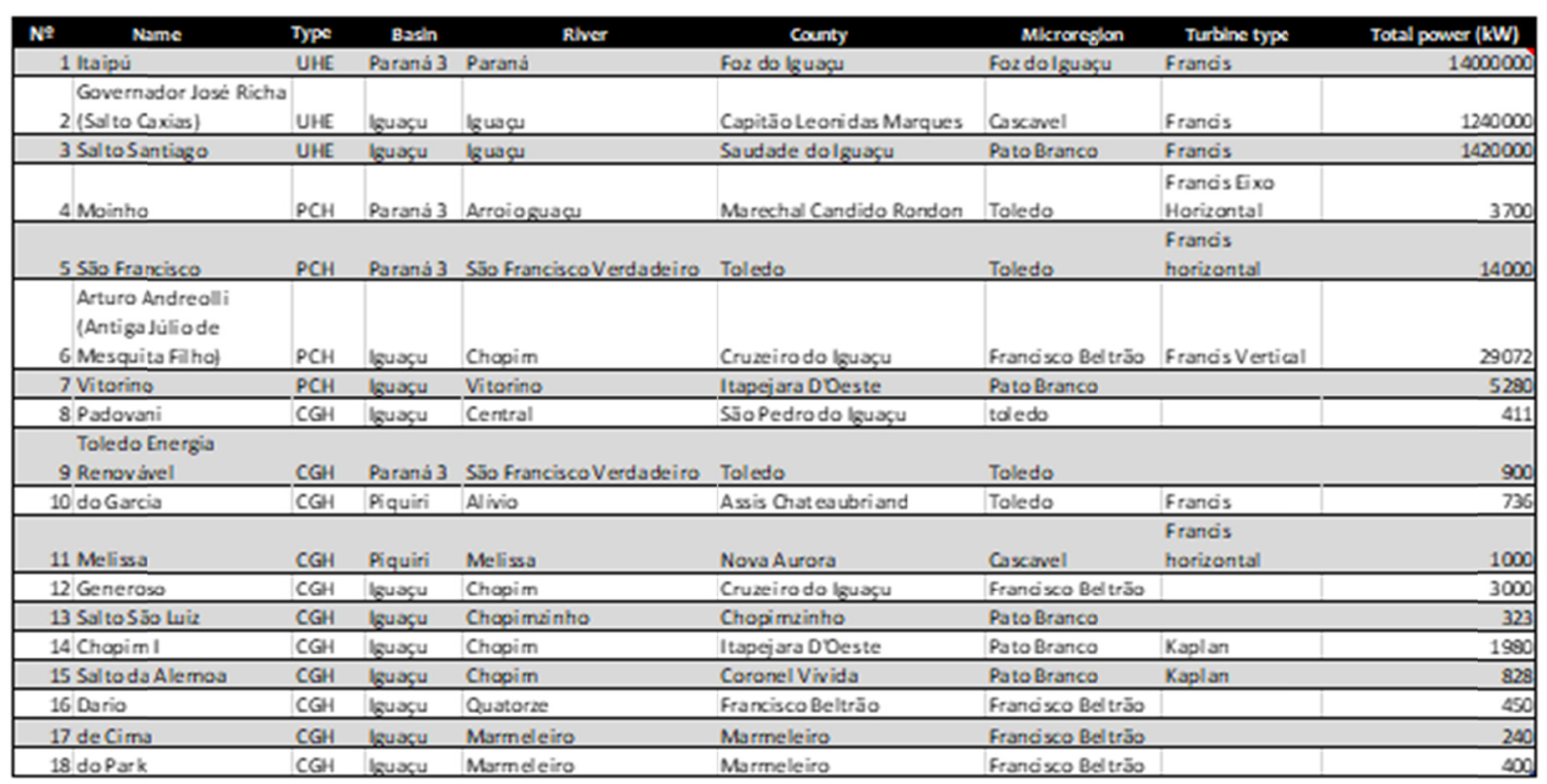

Figure 18. Map with the distribution of hydroenergetic developments in the West and Southwest of Paraná together with their Characterization 


\section{Conclusion}

The increase in demand for electric power will grow linearly in the coming years, requiring the energy matrix to be prepared to absorb such demand. Although this matrix diversifies over the years, hydropower plants are still fundamental due to the stability it generates in the electrical system.

The West and Southwest of Paraná have significant hydropower use in relation to the existing use in other regions of the country with more than $16 \%$ of the total installed capacity, denoting great observance of these uses, since problems with generation in these regions can mean problems in the system in all of Brazil. The main source of the hydropower generation in the West and Southwest of Paraná comes from the Itaipu plant, which holds $84 \%$ of all potential installed in the West and Southwest regions of Paraná.

There are also some hydroelectric projects to be installed in the West and Southwest regions of Paraná, highlighting the HPs that will be in operation or will be installed in the Iguaçu and Piquiri rivers. However, the two regions may, depending on their hydroelectric potential, install SHPs or PGHs to be connected to the grid in the format of ANEEL Resolution 412, reducing energy costs for their owners, as well as collaborating with the Brazilian energy matrix and its stability. These possibilities can be verified in the conceptual map, showing an idea of all the water drainage area of the West and Southwest regions of Paraná.

Considering the temporal analysis of the flows of the Salto Santiago plant in the Iguaçu River watershed and the Melissa plant located in the Piquiri River watershed, it has been verified that in the last fifteen years there has not been a significant change in relation to these flows, having to maintain them practically unchanged considering the expressions generated in the graphs that represent the tendency of the flows of the rivers belonging to those watersheds.

\section{References}

ANEEL. (2015). Resolução Normativa $N^{o} 687$ de 24 de Novembro de 2015. Brasília, Brazil. Retrieved from $\mathrm{http} / /$ www.ans.gov.br/component/legislacao/?view=legislacao\&task=TextoLei\&format=raw\&id=MzUwM $\mathrm{g}==$

ANEEL. (2017). Banco de Informações de Geração. Retrieved from http://www2.aneel.gov.br/aplicacoes/ capacidadebrasil/capacidadebrasil.cfm

Blois, H. D., Paris, E., Carvalho, M. P., \& nunes, B. B. (2017). Forestry: Prospective scenarios for generating electricity Journal of Environmental Management and Sustainability, 6(1), 140-159. https://doi.org/10.5585/ geas.v6i1.488

Casagrande, A. E., \& Souza, E. C. (2013). Do planejamento ao ordenamento territorial: Estudo da região Costa Oeste do Paraná. Raega, 28, 67-85. https://doi.org/10.5380/raega.v28i0.32301

DaftLogic. (2018). Retrieved from https://www.daftlogic.com/sandbox-google-maps-find-altitude.htm

EPE. (2015). Plano Decenal de Expansão de Energia 2024. Ministério de Minas e Energia, Rio de Janeiro. Retrieved from http://www.epe.gov.br/pt/publicacoes-dados-abertos/publicacoes/Plano-Decenal-de-Expans ao-de-Energia-2024

EPE. (2016). Demanda de Energia 2050. Ministério de Minas e Energia, Rio de Janeiro. Retrieved from http://www.epe.gov.br/pt/publicacoes-dados-abertos/publicacoes/Plano-Nacional-de-Energia-2050

Filho, L. M. (2013). Estudo da viabilidade e previsibilidade das chuvas e vazões sazonais na bacia do Rio Iguaçu. Curitiba, Paraná, Brasil: Universidade Federal do Paraná.

IBGE. (1990). Divisão Regional do Brasil em mesorregiões e microrregiões geográficas. Ministério da Economia, Fazenda e planejamento, Rio de Janeiro. Retrieved from https://www.ibge.gov.br/geociencias/ cartas-e-mapas/redes-geograficas/15778-divisoes-regionais-do-brasil.html

IEA. (2012). Technology Roadmap. Hydropower. Ministério de Minas e Energia, Paris: OECD/IEA. Retrieved from https://www.worldcat.org/title/technology-roadmap-hydropower/oclc/819317843

Kliemann, B. K., \& Delariva, R. L. (2015). Pequenas Centrais Hidrelétricas: Cenários e perspectivas no estado do Paraná. Ciência e Natura, 37, 274-283. https://doi.org/10.5902/2179460X17111

Magalhães, M. V. (1998). Movimentos migratórios na Região Sul. IPADES.

Neto, J. V., Santos, C. B., Torres, É. M., \& Estrela, C. (2017). Boxplot: Um recurso gráfico para a análise e interpretação. Robrac, 26(76), 1-6.

Neto, M. R., \& Carvalho, P. M. (2013). Geração de Energia Elétrica - Fundamentos (1st ed.). São Paulo: Erica. 
Oliveira, R. A., \& Moura, M. R. (2015). Consumo de energia elétrica: Uma análise de fonte alternativa de coletor solar de baixo custo. Perspectiva Online, 13(5), 15-26. https://doi.org/10.25242/88765132015729

Secretaria de Meio Ambiente e Recursos Hídricos. (2008). Avaliação Ambiental Integrada-Bacia Piquiri. Retrieved from http://www.iap.pr.gov.br/modules/conteudo/conteudo.php?conteudo=1074

Zatta, R. (2016). A colonização oficial do Sudoeste paranaense e mito do Vazio demográfico. XV Encontro regional de História. Retrieved from http://www.encontro2016.pr.anpuh.org/resources/anais/45/14661251 79_ARQUIVO_TrabalhoAnpuhPR2016RonaldoZatta.pdf

\section{Notes}

Note 1. Three watersheds are said because the watershed of the Iguaçu River is divided in three: the watershed of the Low Iguaçu, of the average Iguaçu and the high Iguaçu.

\section{Copyrights}

Copyright for this article is retained by the author(s), with first publication rights granted to the journal.

This is an open-access article distributed under the terms and conditions of the Creative Commons Attribution license (http://creativecommons.org/licenses/by/4.0/). 